\title{
Media Optimization in Immobilized Culture to Enhance the Content of Curcumin in Curcuma longa (Zingiberaceae) and Protein Profile of Treated Samples in Static Culture
}

Pratibha Chaturvedi $^{1 *}$, Sandeepan Mukherjee ${ }^{2}$, Shraddha Mehta², Pialy Chatterjee and Abhay Chowdhary ${ }^{3}$

${ }^{1}$ Division of Phytopharmacuetics, Haffkine Institute for Training, Testing and Research, Parel, Mumbai, India

${ }^{2}$ Department of Virology, Haffkine Institute for Training, Testing and Research, Parel, Mumbai, India

${ }^{3}$ Director, Haffkine Institute for Training, Testing and Research, Parel, Mumbai, India

\begin{abstract}
Plant cell culture system has served as an alternative to enhance the production of high value phyto-pharmaceuticals. In the described study, the immobilized culture and static culture of Curcuma longa (Zingiberaceae) were used to maximize the production of the bioactive compound Curcumin. It was observed that Curcumin content in vitro studies (static as well as immobilize cultures) were enhanced in one week old cultures fed with $5 \mathrm{mg} / 100 \mathrm{ml}$ of media (Static $8.71 \%$; immobilize $2.03 \%$ ). Statistically significant (seven fold) enhancement in Curcumin content was obtained in one week old static culture, which was maintained on Zenk production media incorporated with cinnamic acid (Control $1.57 \%$ and induced $8.717 \%$ ). Quantitative estimation was done using HPTLC analysis with standard Curcumin. To evaluate the effect of treatment on total protein in Curcumin biosynthesis, we have examined Curcumin content as well as the protein profile of treated samples of Curcuma longa static culture. All the treated samples were analysed using SDS-PAGE for their proteomic profiles. A 23,420 Da protein was prominently expressed in all samples which may be a glycine rich protein (works on defence mechanism). Treated samples exhibited decreased expression of the protein as compared to control. This may be attributed to the formation of Reactive Oxygen species (ROS) in culture condition due to high concentration of sucrose $(5 \%)$ in the Curcuma longa culture media that is known to induce oxidative stress and subsequent increase in Curcumin production. Further investigation is required to understand the actual protein involvement in Curcumin synthesis in different cultures treated with different compounds. The study signifies the use of plant explants to develop immobilized and static cultures rather than callus in Zenk media, which reduce the time as well as expenditure. The proteomic profile of $C$. longa has been discussed earlier, but its effect on proteomic profile of in vitro treated samples is a new study.
\end{abstract}

Keywords: Immobilize culture; Curcuma longa; Curcumin; Protein profile

\section{Introduction}

Plants in Zingiberaceae family are widely distributed in many countries of Southeast Asia. In Thailand at least two-hundred species of Zingiberaceous plants are found and these include members of various genera, such as Alpinia, Amomum, Curcuma, Etlingera, Kaempferia, and Zingiber [1,2]. Zingiberaceous plants have been widely used in traditional medicine, as well as food flavouring and spice agents. Many studies have focused on the bioactive small organic compounds from these plants and have supported the traditional medicinal use of the plant extracts, such as Curcumin [3], sesquiterpene [4-6], and various essential oils [7-9], flavonoids and phenolic compounds [10,11]. Their actual physiological functions are likely to be in the defence against phytophagous predators (mostly insects) and phytopathogenic microorganisms [12,13]. Kumar, 2010 have reported the antioxidant protein turmerin from Curcuma longa by using SDS PAGE technique. This protein was examined for its ability to prevent oxidative organ damage against Naja naja venom phospholipase $A_{2}$ in male swiss wistar mice. Discoveries of cell cultures capable of producing specific medicinal compounds at a rate similar or superior to that of intact plants have accelerated in the last few years and has been well reviewed. In order to obtain high yields suitable for commercial exploitation, efforts have been focused on isolating the biosynthetic activities of cultured cells, achieved by optimizing the cultural conditions and employing precursor feeding [14]. The current yield and productivity cannot fulfil the commercial goal of plant cell-based bioprocess for the production of most secondary metabolites, hence we have developed the novel protocol to enhance the Curcumin content in tissue culture system as also to reduce the cost of it 's production. Cell cultures have a higher rate of metabolism than intact differentiated plants because the initiation of cell growth in culture leads to fast proliferation of cell mass and to a condensed biosynthetic cycle. This is the most important advantage of plant cell cultures as model systems for the study of biosynthetic pathways, as secondary metabolite formation can take place within a short cultivation time (about 2-4 weeks).With emerging trends of exploiting plant cell culture for the production of high value phyto-pharmaceuticals; immobilization of plant cell has a very important role. Immobilization can overcome many limiting factors of suspension culture with distinct advantage of easier separation from product and also being amenable for biotransformation of low value compounds to higher value product [14].

One of the main problems encountered is the lack of basic knowledge of the biosynthetic routes and mechanisms responsible for the production of plant metabolites, so the developed protocol is also helpful in understanding the biosynthetic pathway of the end product (natural product). The proteomic profile of $C$. longa has been discussed earlier [1], but proteomic profile of in vitro treated samples is a new kind of study. Keeping all the facts, the Curcuma longa tissue samples that have been induced by different compounds in vitro system aseptically

*Corresponding author: Pratibha Chaturvedi, Division of Phytopharmacuetics, Haffkine Institute, Parel, Mumbai - 400012, India, Tel: +9122-24160962241; E-mail: pratibha.c@rediffmail.com

Received July 01, 2014; Accepted July 18, 2014; Published July 20, 2014

Citation: Chaturvedi P, Mukherjee S, Mehta S, Chatterjee P, Chowdhary A (2014) Media Optimization in Immobilized Culture to Enhance the Content of Curcumin in Curcuma longa (Zingiberaceae) and Protein Profile of Treated Samples in Static Culture. Nat Prod Chem Res S1:002. doi: 10.4172/2329-6836.S1-002

Copyright: (c) 2014 Chaturvedi P, et al. This is an open-access article distributed under the terms of the Creative Commons Attribution License, which permits unrestricted use, distribution, and reproduction in any medium, provided the original author and source are credited. 
Citation: Chaturvedi P, Mukherjee S, Mehta S, Chatterjee P, Chowdhary A (2014) Media Optimization in Immobilized Culture to Enhance the Content of Curcumin in Curcuma longa (Zingiberaceae) and Protein Profile of Treated Samples in Static Culture. Nat Prod Chem Res S1:002. doi:10.4172/2329-6836.S1-002

Page 2 of 2

(static and immobilized) were analysed for Curcumin contents also for the protein profile which made a clear perception on tentative protein that has a role in biosynthesis of desire compound.

\section{Material and Method}

\section{Static culture of Curcuma longa for enhancement of curcumin}

Rhizome of C. longa has been collected from the local market Mumbai (Latitude: $18^{\circ} 96^{\prime} 50^{\prime \prime} \mathrm{N}$ Longitude: $72^{\circ} 82^{\prime} 53^{\prime \prime} \mathrm{E}$ ) and identified by Botanist of Haffkine Institute. Here we are focusing on the enhancement of this poly phenolic compound in rhizome tissue rather than callus in vitro system. The experiment is based on the dual strategies that were used by Zenk et al., for alkaloid production in Catharanthus roseus tissue culture. The experiment involves the transfer of biomass into production media that favours the production and accumulation of secondary metabolites. Here we have used Zenk media as basal media supplemented with different concentration of cinnamic acid and Tyrosine separately and $5 \%$ sucrose. $\mathrm{pH}$ was 5.6 before autoclaving. Sterile media, Autoclaved on $121^{\circ} \mathrm{C}$ were used to aseptic inoculation in laminar hood. Here it is mentioned that both compounds are intermediate compounds in biosynthetic pathway of Curcumin [15].
The inoculated cultures were maintained at $26 \pm 1^{\circ} \mathrm{C}, 70 \%$ humidity with 16 hours of light (1000 lux) and 8 hours of dark period in growth room. The different tissue samples were harvested at the age of 1 week separately, weighed and subjected for cold extraction in ethanol $(\mathrm{w} / \mathrm{v})$ at room temperature. After 48 hours the extracts were dried, weighed and subjected for High Performance Thin Layer Chromatography (HPTLC) analysis. Statistical analysis was done by using Annova test (Graph pad prism) in triplicate (Figure 1).

\section{Immobilize suspension culture for enhancement of curcumin}

The fresh rhizome was washed with teepol and rinsed in running tap water. Rhizome explant ( $2 \mathrm{gm}$ ) was sterilized with $0.1 \%$ mercuric chloride for $2 \mathrm{~min}$ followed by three times wash with sterile water, aseptically and homogenized in mortar and pestle. Homogenate materials were then passed through net $(425 \mu \mathrm{m})$, to remove the large cell aggregate and fibrous material. Homogenate tissue was suspended in $2 \%$ sodium alginate $(10 \mathrm{ml})$ and the suspension was added drop wise to $50 \mathrm{mM}$ Calcium chloride through sterilized needle and syringe. The alginate beads of diameter 2-3 $\mathrm{mm}$ were formed and were left in $\mathrm{CaCl}_{2}$ solution for $30 \mathrm{~min}$ for the stabilization of beads and then washed with sterilized water separately.
A

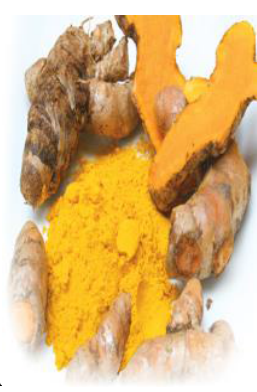

B

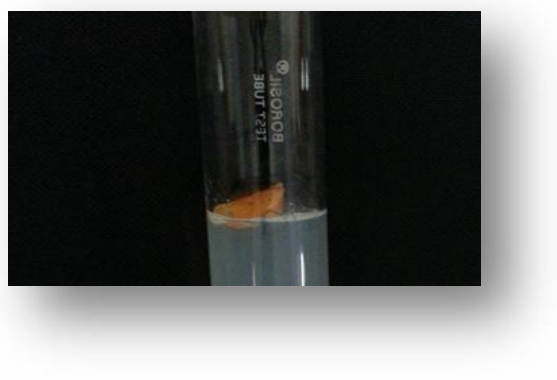

$\mathbf{E}$

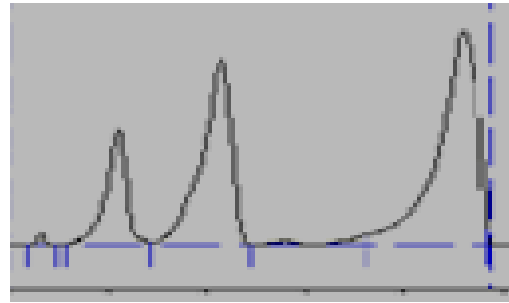

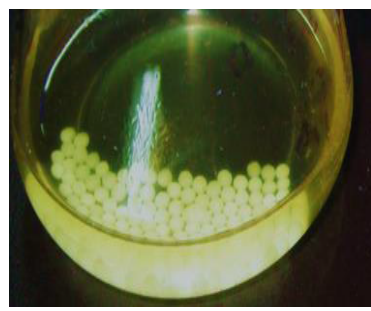

C
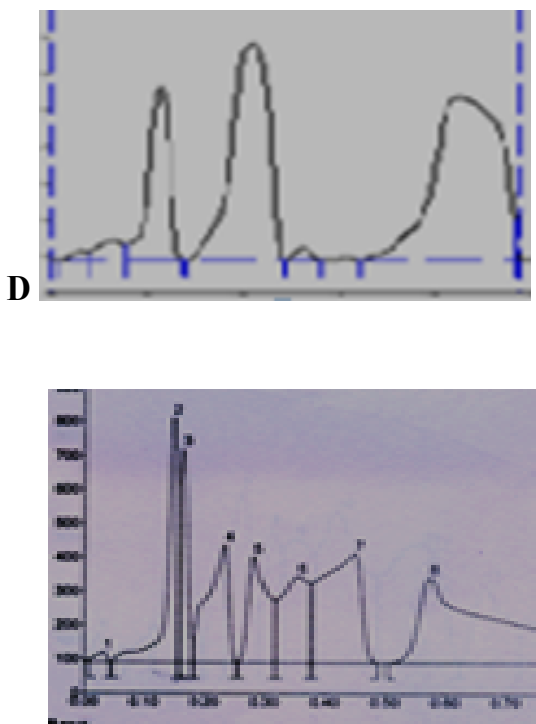

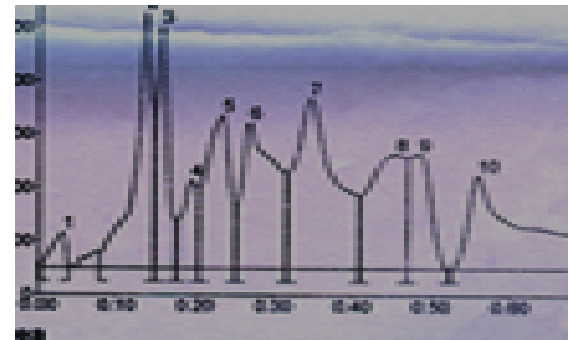

$\mathbf{F}$

Figure 1: A: Curcuma longa rhizome; B: C. longa static culture; C: C.longa immobilize culture; D, E: HPTLC Chromatogram of immobilize culture at 425 nm induced with Standard of Curcumin; F,G: HPTLC Chromatogram of Curcumin in static culture of Curcuma longa with standard Curcumin standard at 525 nm. 
Citation: Chaturvedi P, Mukherjee S, Mehta S, Chatterjee P, Chowdhary A (2014) Media Optimization in Immobilized Culture to Enhance the Content of Curcumin in Curcuma longa (Zingiberaceae) and Protein Profile of Treated Samples in Static Culture. Nat Prod Chem Res S1:002. doi:10.4172/2329-6836.S1-002

Page 3 of 2

Calcium alginate entrapped cells (300 beads) were kept in Zenk suspension media supplemented with $40 \mathrm{mg} / 100 \mathrm{ml}, 60 \mathrm{mg} / 100$ $\mathrm{ml}$ of Tyrosine and $5 \mathrm{mg} / 100 \mathrm{ml}, 7.5 \mathrm{mg} / 100 \mathrm{ml}$ of cinnamic acid in Erlenmeyer flasks $250 \mathrm{ml}$ capacity separately. They were kept in Remi shaker cum incubator at $90 \mathrm{rpm}$ and $25 \pm 20^{\circ} \mathrm{C}$ for one week duration.

\section{Extraction and estimation for curcumin content}

Curcuma longa beads were harvested after one week and extracted in ethanol for Curcumin. All samples were centrifuged. The supernatant of centrifuged extracts were dried, weighed and subjected for further qualitative as also quantitative estimation. Curcumin content were analysed with respective standard compound of Curcumin (purchased from Sigma Alderich) by using High Performance Thin Layer Chromatography (HPTLC).

\section{High Performance Thin Layer Chromatography (HPTLC)}

High Performance Thin Layer Chromatography of all samples was carried out in Khalsa College, Matunga (E) with standard compound of Curcumin (Rf value 0.76). Inert gas was used as spray gas in CAMAG LINOMAT 121037 HPTLC equipment and Chloroform: Methanol (9:1) was used as mobile phase.

\section{Protein extraction}

Fresh treated tissue of Curcuma longa rhizome samples were grinded to a powder with liquid nitrogen in a mortar and pestle separately. Briefly, the plant powder ( $5 \mathrm{~g}$ ) was extracted by suspension in $20 \mathrm{~mL}$ of extraction buffer $(0.5 \mathrm{M}$ Tris, $30 \mathrm{mM} \mathrm{HCl}, 0.1 \mathrm{M} \mathrm{KCl}, 0.7 \mathrm{M}$ sucrose and $1 \%(\mathrm{v} / \mathrm{v}) \beta$-mercaptoethanol) for $30 \mathrm{~min}$ at $4^{\circ} \mathrm{C}$, whereupon the supernatant was then collected by centrifugation at $4,000 \times \mathrm{g}$ for 10 min. The precipitate was extracted twice in extraction buffer and the extracts were then extracted with a $1: 5(\mathrm{v} / \mathrm{v})$ ratio of water-saturated phenol at $4^{\circ} \mathrm{C}$ for $60 \mathrm{~min}$. After phase separation the phenol phase were then harvested and proteins were precipitated from the phenol phase by the addition of a four-volume of $0.1 \mathrm{M}$ ammonium acetate in methanol and left overnight at $-20^{\circ} \mathrm{C}$. The resulting phenol-soluble protein pellet were collected by centrifugation at $4,000 \times \mathrm{g}$ for $10 \mathrm{~min}$, re suspended in cold water with sonication for $3 \mathrm{~min}$ and then precipitated again in nine volumes of cold acetone at $-20^{\circ} \mathrm{C}$ for $2 \mathrm{~h}$ and centrifuged at $4,000 \times \mathrm{g}$ for $10 \mathrm{~min}$. The protein pellet was air-dried to remove the acetone. The extracts were separately extracted with the equal volume of ethyl acetate and made a layer of EA, was in rich volume of pigments ,the rest of the lower layer was separated and the hence we obtained the protein rich portion of the extracts. The amount of protein in each sample was determined by the Bradford assay [16] using BioTeK multimode synergy 2 readers.

\section{SDS Page}

The protein were separated on $5 \%$ stacking and $10 \%$ resolving polyacrylamide gel. The gel was stained by silver staining method and scanned on image scanner. All samples were mixed with sample buffer (loading buffer). Heat them in boiling water for 5-10 min. Load prepared samples into wells and make sure not to overflow. We have used loading protein marker in the first lane. Then covered the top and connect the anodes. Set an appropriate volt and run the electrophoresis when everything's done. As for the total running time, stop SDS-PAGE running when the down most sign of the protein marker (if no visible sign, inquire the manufacturer) almost reaches the foot line of the glass plate. Generally, about 1 hour for a $120 \mathrm{~V}$ voltage and a $12 \%$ separating gel. For a separating gel possessing higher percentage of acrylamide, the time will be longer. The bands of protein profile was analysed on the basis of ladder. Quantification of the possibly Glycine rich protein band of all samples was carried out by using Gel Quant NET software (Figure 2).

\section{Results and Discussion}

Plant cells are biosynthetically totipotent, which means that each cell in culture retains complete genetic information and hence is able to produce the range of chemicals found in the parent plant. Antioxidant proteins (Turmerin) have previously been reported in Curcuma longa [17]. The osmotic stress created by sucrose alone and with other osmotic agents was found to regulate anthocyanin production in Vitis vinifera cell suspension cultures [18]. Along with this, the phosphate concentration in the medium can have a major effect on the production of secondary metabolites in plant cell cultures. Higher levels of phosphate were found to enhance the cell growth, where it had negative influence on secondary product accumulation, whereas in lower level that favour to maximize the production of secondary metabolites [19]. In the described study, we have used Zenk production media as basal media in tissue culture system in which, sucrose was used in $5 \%$ with different concentration of cinnamic acid and Tyrosine. Improvement in the secondary metabolite production of cell cultures is often associated with the organization and differentiation of plant cells that led to the use of immobilization technology. Immobilization in cell culture has been reviewed by many workers [20]. Seven fold enhancements in Curcumin content was observed in one-week old static culture, which was


Figure 2: Showing Curcumin \% content in Static (A) and Immobilize culture (B) SD mean of Three replicates Statistical analysis was done by using Annova test. 
Citation: Chaturvedi P, Mukherjee S, Mehta S, Chatterjee P, Chowdhary A (2014) Media Optimization in Immobilized Culture to Enhance the Content of Curcumin in Curcuma longa (Zingiberaceae) and Protein Profile of Treated Samples in Static Culture. Nat Prod Chem Res S1:002. doi:10.4172/2329-6836.S1-002

Page 4 of 2

maintained on Zenk production media incorporated with $5 \mathrm{mg} / 100 \mathrm{ml}$ of Cinnamic acid (Control 1.57\% and induced 8.717\%). In immobilized culture studies, Curcumin content was higher in one-week old $(2.03 \% /$ 300 beads) immobilized suspension culture supplemented with Zenk basal media and $5 \mathrm{mg} / 100 \mathrm{ml}$ of cinnamic acid (Table 1). Cinnamic acid and Tyrosine compounds are intermediate compounds in biosynthetic pathway of Curcumin. Secondary metabolites in cell culture have been enhanced by many scientists by following this strategy [20]. It's production has been well reviewed in static as well as suspension culture of medicinal plants $[15,21,22]$

In Protein profile studies, all the treated samples were analysed for their proteomic profile using SDS PAGE and it was observed that protein of 23,420 D was most prominent in all samples (Figure 3). This may be of Glycine rich Protein (works on defence mechanism) which is already reported in Curcuma comosa [23]. There are some reports that support the hypothesis that biological damage mediated by the occurrence of ROS can be generated by abiotic stress [24-26]. The expression of protein (based on intensity of the bands) was reduced in treated samples as compared to control; this may be due to the

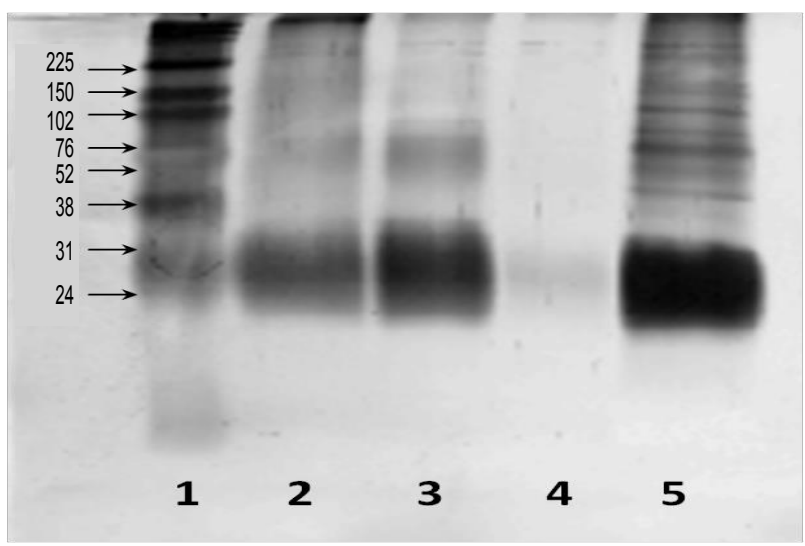

Figure 3: Showing the protein profile of induce samples 2,3,4 (Tyrosine 60 $\mathrm{mg} / 100 \mathrm{ml}$, Tyrosine $40 \mathrm{mg} / 100 \mathrm{ml}$, Cinnamic acid $7.5 \mathrm{mg} / 100 \mathrm{ml}$ ) with ladder 1 and 5 control. Figure showing the expression of $24 \mathrm{KD}$ band in all the instances which is most prominent in Curcuma longa tissue fed with Tyrosine $40 \mathrm{mg} / 100$ $\mathrm{ml}$ of Zenk media in static culture. However the tissue fed with $5 \mathrm{mg} / 100 \mathrm{ml}$ of Cinnamic acid in Zenk media did not express any band.

\begin{tabular}{|l|l|c|c|}
\hline \multirow{2}{*}{ S.no } & Media content & $\begin{array}{c}\text { Curcumin content } \\
\text { \% of Curcuma } \\
\text { longa/300 beads in } \\
\text { immobilize culture }\end{array}$ & $\begin{array}{c}\text { Curcumin content } \\
\text { \% of Curcuma } \\
\text { longa in static } \\
\text { culture FW }\end{array}$ \\
\cline { 2 - 4 } One week & One week \\
\hline 1. & Tyrosine $40 \mathrm{mg} / 100 \mathrm{ml}$ & $1.4 \pm 0.190$ & $5.9 \pm 0.02$ \\
\hline 2. & Tyrosine $60 \mathrm{mg} / 100 \mathrm{ml}$ & $1.66 \pm 0.07$ & $6.22 \pm 0.078$ \\
\hline 3. & Cinnamic acid $5 \mathrm{mg} / 100 \mathrm{ml}$ & $2.03 \pm 0.03$ & $8.71 \pm 0.02$ \\
\hline 4 & Cinnamic acid $7.5 \mathrm{mg} / 100 \mathrm{ml}$ & $1.7 \pm 0.2$ & $7.91 \pm 0.136$ \\
\hline 5. & Control & \multicolumn{2}{|c|}{$1.5 \pm 0.071$} \\
\hline
\end{tabular}

Table 1: Effect of different compounds on Curcumin production in immobilized culture and static culture of Curcuma longa \pm Mean S.D (Annova test) of three replicates statistically significant $\mathrm{P}<0.05 \mathrm{FW}-$ Fresh weight.

\begin{tabular}{|l|l|l|}
\hline S. No & Media used & Relative Band Intensity \\
\hline 1. & Tyrosine $60 \mathrm{mg} / 100 \mathrm{ml}$ & $41.79 \%$ \\
\hline 2. & Tyrosine $40 \mathrm{mg} / 100 \mathrm{ml}$ & $65.53 \%$ \\
\hline 3. & Cinnamic acid $7.5 \mathrm{mg} / 100 \mathrm{ml}$ & $1.64 \%$ \\
\hline 4. & Control & $100.00 \%$ \\
\hline
\end{tabular}

Table 2: Showing the band intensity (\%) of possibly Glycine Rich Protein in induced samples of Curcuma longa tissue culture. formation of Reactive Oxygen species (ROS) in culture condition and which modified the protein. In this case, increased level of sucrose than MS media (5\%) has been added to Curcuma longa culture media, which is known inducer of oxidative stress (abiotic stress) and eventually the Curcumin production is increased. The protein profile expression was down regulated in all treated samples. Maximum intensity is expressed by tissue grown in Tyrosine $40 \mathrm{mg} / 100 \mathrm{ml}$ (Relative intensity of Glycine rich protein: $65.53 \%$ w.r.t control) which is comparable to control (Table 2). The significant part of the research is to use the plant explants as source to develop immobilize culture and static culture rather than callus in Zenk production media, which reduce the time as well as expenditure and is new protocol; (Table 1). Large number of studies has focussed on the production of secondary metabolites in C. longa. However the exact mechanisms of ROS generation and its implication on the synthesis of stress specific metabolites have remained unanswered. The present study is a preliminary indicator of the changes in stress related proteins (e.g. possibly Glycine Rich Protein) with respect to induction of abiotic stress. Further studies encompassing complete proteome profiles are warranted to understand the mechanisms behind such phenomenon. After observing the results, it can be assumed that in stress condition, the protein may take part in the biosynthesis of Curcumin and itself get reduced .The present study is useful for the pharmaceutical industries which can enhance the Curcumin production by giving abiotic stress. These will not only enlighten us regarding the molecular mechanisms of plant stress physiology, but shall also provide new insights into developing protocols to enhance plant secondary metabolites.

\section{References}

1. Sirirugsa $P$ (1998) Thai Zingiberaceae Species diversity and their uses. Pure Appl Chem 70: 2111-2118.

2. Shehzad A, Wahid F, Lee YS (2010) Curcumin in cancer chemoprevention: molecular targets, pharmacokinetics, bioavailability, and clinical trials. Arch Pharm (Weinheim) 343: 489-499.

3. Sun XY, Zheng YP, Lin DH, Zhang H, Zhao F, et al. (2009) Potential anti-cancer activities of Furanodiene, a Sesquiterpene from Curcuma wenyujin. Am J Chin Med 37: 589-596.

4. Kim M, Miyamoto S, Yasui Y, Oyama T, Murakami A, et al. (2009) Zerumbone a tropical ginger sesquiterpene, inhibits colon and lung carcinogenesis in mice. Int J Cancer 124: 264-271.

5. Makabe H, Maru N, Kuwabara A, Kamo T, Hirota M (2006) Anti-inflammatory sesquiterpenes from Curcuma zedoaria. Nat Prod Res 20: 680-685.

6. Chopra IC, Jamwal KS, Khajuria BN (1954) Pharmacological action of some common essential oil-bearing plants used in indigenous medicine. I. Pharmacological action of Acorus calamus, Curcuma zedoaria, Xanthoxylum alatum and Angelica archangelica. Indian J Med Res 42: 381-384

7. Kojima H, Yanai T, Toyota A (1998) Essential oil constituents from Japanese and Indian Curcuma aromatica rhizomes. Planta Med 64: 380-381.

8. Lai EY, Chyau CC, Mau JL, Chen CC, Lai YJ, et al. (2004) Antimicrobial activity and cytotoxicity of the essential oil of Curcuma zedoaria. Am J Chin Med 32 281-290.

9. Kundu JK, Na HK, Surh YJ (2009) Ginger-derived phenolic substances with cancer preventive and therapeutic potential. Forum Nutr 61: 182-192.

10. Ghasemzadeh A, Jaafar HZ, Rahmat A (2010) Antioxidant activities, tota phenolics and flavonoids content in two varieties of Malaysia young ginger (Zingiber officinale Roscoe). Molecules 15: 4324-4333.

11. Chrispeels MJ, Raikhel NV (1991) Lectins, lectin genes, and their role in plant defense. Plant Cell 3: 1-9.

12. Damme EJM (2008) Plant Lectins as Part of the Plant Defense System against Insects. Induced Plant Resistance to Herbivory 285-289.

13. Morris P, Rudge K, Cresswell R, Fowler MW (1986) Regulation of Product Synthesis in Cell Culture of Catharanthus roseus. Planta Medica. 127-132.

14. Chokchaichamnankit D, Subhasitanont $P$, Paricharttanakul NM, Svasti J, 
Citation: Chaturvedi P, Mukherjee S, Mehta S, Chatterjee P, Chowdhary A (2014) Media Optimization in Immobilized Culture to Enhance the Content of Curcumin in Curcuma longa (Zingiberaceae) and Protein Profile of Treated Samples in Static Culture. Nat Prod Chem Res S1:002. doi:10.4172/2329-6836.S1-002

Sangvanich P, Srisomsap C(2009). Proteomic Alterations during Dormant Period of Curcuma longa Rhizomes. J Proteomics Bio inform 2: 380.

15. Bradford MM (1976) A rapid and sensitive method for the quantitation of microgram quantities of protein utilizing the principle of protein-dye binding. Anal Biochem 72: 248-254

16. Kumar MC (2010) Isolation and characterization of an antioxidant protein from Turmeric (Curcuma longa L.) peel waste: A new biological source. Journal of Pharmacy Research 3: 2659-2662.

17. DiCosmo F, Misawa M (1995) Plant cell and tissue culture: alternatives for metabolite production. Biotechnol Adv 13: 425-453.

18. Zenk MH, el-Shagi $H$, Schulte $U$ (1975) Anthraquinone production by cell suspension cultures of Morinda citrifolia. Planta Med Suppl: 79-101.

19. Yeoman MM, Holden MA, Corchet P, Holden PR, Goy JG, Hobbs MC(1990) Exploitation of disorganized plant cultures for the production of secondary metabolites. In: Charlwood BV, Rhodes M J C, editors. Secondary products from plant tissue culture. Oxford: Clarendon Press, 139-66.

20. Chaturvedi $P$, Khanna $P$, Chowdhary A (2012) In vitro Production of Secondary Metabolites from Some Medicinal Plants Lambert publications Germany.74.
21. Chaturvedi P, Chowdhary A (2014) A novel method for bio-enhancement of anti-cancerous compound Curcumin in vitro tissue culture of Curcuma longa (Apiaceae). The Journal of bioprocess Technology 99: 389-395

22. Chaturvedi P, Chowdhary A (2013) Enhancement of antioxidant compound in Tylophora indica callus. Advances in Applied Science Research 24: 325-330.

23. Boonmee A, Srisomsap C, Chokchaichamnankit D, Karnchanatat A, Sangvanich P (2011) A proteomic analysis of Curcuma comosa Roxb. rhizomes. Proteome Sci 9: 43.

24. Abd El-Moneim MR, Mohamed MR, Ebtesam AM, Hossam S EL-B(2011) Effect of Gamma Radiation on Protein Profile, Protein Fraction and Solubility's of Three Oil Seeds: Soybean, Peanut and Sesame Abd El-Not Bot Horti Agrobo 39: $90-98$.

25. Cushman JC (1993) Molecular cloning and expression of chloroplast NADPmalate dehydrogenase during Crassulacean acid metabolism induction by salt stress. Photosynth Res 35: 15-27.

26. Subramanian B, Bansal VK, Kav NN (2005) Proteome-level investigation of Brassica carinata-derived resistance to Leptosphaeria maculans. J Agric Food Chem 53: 313-324. 